\title{
Private governance responsibilisation in global supply chains: the case of Rana Plaza
}

DOI:

10.1108/AAAJ-05-2019-3993

\section{Document Version}

Accepted author manuscript

Link to publication record in Manchester Research Explorer

\section{Citation for published version (APA):}

Siddiqui, J., McPhail, K., \& Rahman, S. S. (2020). Private governance responsibilisation in global supply chains: the case of Rana Plaza. Accounting, Auditing and Accountability Journal, 33(7), 1569-1594.

https://doi.org/10.1108/AAAJ-05-2019-3993

\section{Published in:}

Accounting, Auditing and Accountability Journal

\section{Citing this paper}

Please note that where the full-text provided on Manchester Research Explorer is the Author Accepted Manuscript or Proof version this may differ from the final Published version. If citing, it is advised that you check and use the publisher's definitive version.

\section{General rights}

Copyright and moral rights for the publications made accessible in the Research Explorer are retained by the authors and/or other copyright owners and it is a condition of accessing publications that users recognise and abide by the legal requirements associated with these rights.

\section{Takedown policy}

If you believe that this document breaches copyright please refer to the University of Manchester's Takedown Procedures [http://man.ac.uk/04Y6Bo] or contact uml.scholarlycommunications@manchester.ac.uk providing relevant details, so we can investigate your claim.

\section{OPEN ACCESS}




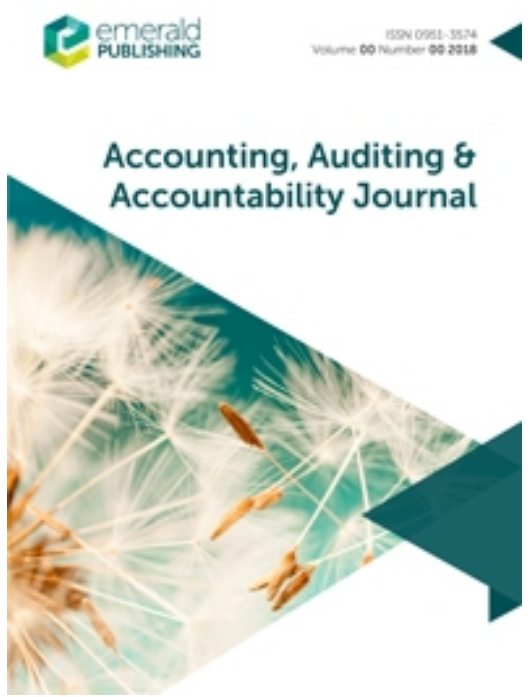

\section{PRIVATE GOVERNANCE RESPONSIBILISATION IN GLOBAL SUPPLY CHAINS: THE CASE OF RANA PLAZA}

\begin{tabular}{|r|l|}
\hline Journal: & Accounting, Auditing \& Accountability Journal \\
\hline Manuscript ID & AAAJ-05-2019-3993.R3 \\
\hline Manuscript Type: & Research Paper \\
\hline Keywords: & $\begin{array}{l}\text { Certification, Supply chain, Governance, Political, Sustainability, Social } \\
\text { accounting }\end{array}$ \\
\hline \multicolumn{2}{|l}{} \\
\hline
\end{tabular}

\section{SCHOLARONE ${ }^{\text {M }}$ \\ Manuscripts}




\section{PRIVATE GOVERNANCE RESPONSIBILISATION IN GLOBAL SUPPLY CHAINS: THE CASE OF RANA PLAZA}

\section{Introduction}

The failure of nation-states to address supranational governance challenges in supply chains has subsequently led to the development of a growing range of voluntary private governance mechanisms (Bernstein and Cashore, 2007; O’Rourke, 2006; Vogel, 2008). Such private sector-led governance mechanisms and standards, implemented by strict inspection regimes monitored directly by the multinational corporations (MNCs), is considered within the management literature as corporate assumption of a political role (Scherer and Palazzo, 2011; Frynas and Stephens, 2015; Reinecke and Ansari, 2016). Within the management literature, MNCs are often criticised for their unsustainable social and environmental practices in developing countries (Burritt et al, 2018). Jamali (2010), for example, points out that MNCs sometimes act against the interests of host nation by sourcing cheap labour and fostering poor working conditions in supply chains in developing countries. At the same time, prior research has also acknowledged the capability of MNCs in improving working conditions via various employment and community programmes (Malovics et al, 2008). In recent times, several accounting academics (for example, Kouakou, Boiral and Gendron, 2013; Islam et al, 2018; Sinkovics, Hoque and Sinkovics, 2016; Siddiqui and Uddin, 2016) have begun exploring the efficacy of the private governance mechanisms in detail. Especially, following Power's (1997) work on attempts by accountants to compete for work in environmental audit field, the auditing literature has increasingly recognised the potentials of social and environmental audits to offer a robust lens through which concerns over the supply chain and its audit and assessment can be framed and explored (Islam, Deegan and Gray, 2018). Within the social and environmental audit literature, Boiral (2013) uses the notion of spectacles (Debord, 1971) to report the capability of certification mechanisms to present a reassuring façade that hides uncertainties inherent organisational practices and capabilities. Using the case of the ready-made garments (RMG) industry in Bangladesh, Sinkovics et al. (2016) demonstrate how the pressure for compliance has resulted in companies prioritising the implementation of measurable standards over the socially grounded needs and priorities of workers. Within the wider sustainability accounting literature, a growing body of research has explored issues relating to environmental and social compliance audits and assurance (Gray 2000; Owen et al. 2000; O'Dwyer and Owen 
2005; Deegan, Cooper and Shelly, 2006; Owen 2007; Simnett, Vanstrealen and Chua, 2009; Edgley, Jones and Solomon, 2010; O'Dwyer, Owen and Unerman, 2011). Canning, O'Dwyer and Georgakopolous (2018), for example, demonstrate how financial audit-styled concepts such as materiality are transferred to the sustainability assurance process, sometimes by assurors with no financial accounting background. However, this body of research either has had a normative emphasis, or explored the legitimacy or reputation building aspects of such audit process, using different theoretical perspectives (Islam et al., 2018). Darnall, Seol and Sarkis (2009), for example, draw on stakeholder theory to explore an organisation's use of different types of environmental audits, and report a wide variation across stakeholder groups. O'Dwyer et al (2011) use notions of moral, pragmatic and cognitive legitimacy (Suchman, 1995) to explore the process through which such assurance practices are legitimised. In a recent study, Islam et al (2018) identify the limitations of compliance (certification) audits in advancing workers' rights. Drawing on the concept of surrogate accountability, they suggest that some form of surrogate (government, non-governmental organisations or media) intervention is necessary in order to hold MNCs and their suppliers accountable and create real change in workers' conditions.

While this body of research points out the limitations of certifications processes, the accounting and auditing literature has paid relatively scant attention to the social process through which MNCs may come to accept responsibility for resolving governance problems in supply chains, rather than engaging only in compliance or manipulation to avoid sanctions and appear legitimate (Scherer, Palazzo and Seidl, 2013). Reinecke and Ansari (2016) propose that a plausible explanation to this problem lies in a number of frame shifts that gradually change the attitude of stakeholders from denial to acquiescence, and eventually, taking responsibility and assuming a political role in resolving the conflict. They propose a "political responsibilisation framework" involving three drivers that trigger frame changes within supply chains. For the purpose of this paper, we use Reinecke and Ansari's (2016) responsibilisation framework to investigate how a frame-change in the perception of the actors may result in MNCs taking more responsibility in solving a crisis within a supply chain, and make the certification arrangements potentially more effective. In this paper, we apply Reinecke and Ansari's (2016) framework to investigate how responsibilisation for addressing governance problems in the RMG industry in Bangladesh operated post Rana Plaza ${ }^{1}$. Although a probe report following the collapse of the

\footnotetext{
${ }^{1}$ On April 24, 2013, an eight-storey building collapsed completely in Savar, a sub-district of Dhaka, the capital of Bangladesh. The building, named Rana Plaza, hosted several factories that produced ready-made garments
} 
Rana plaza in Bangladesh that killed more than 1,100 workers identified working conditions, low wages, and safety standards as the root cause of the problem (BBC, 2013) $)^{2}$, the RMG sector in Bangladesh has long suffered from several economic and non-economic challenges, such political instability, corruption, and the presence of a state-business nexus which allowed the state to deny any allegations of human rights violations in this sector (Siddiqui and Uddin, 2016). A report published by the Transparency International Bangladesh termed the Rana Plaza accident as a 'as a stark example of lack of good governance and corruption in the RMG sector in Bangladesh' (TIB, 2015) ${ }^{3}$. Following the Rana plaza collapse, both state and non-state actors [such as the MNCs and the private owners of the RMG factories in Bangladesh, as well as the Bangladesh Garments Manufacturers Association (BGMEA), the apex body regulating the RMG industry in Bangladesh] were severely criticised for their failure to accept responsibility for the governance failures in this sector. This eventually resulted in the installation of a private sector-led certification regime, indicating an interest for the MNC's to assume a more political role in tackling the governance problems through their CSR activities (Scherer and Palazzo, 2011). In this context, the paper addresses the following research question: 'How did private sector responsibilisation for the governance failures emerge and evolve post Rana Plaza?'

A crucial element of Reinceke and Ansari's (2016) framework is the catalytic role of the state in the process of addressing a supply chain crisis. Here, the state does not dictate, or enforce behaviour. Alamgir and Banerjee (2019), however, point out that globalisation and the subsequent emergence of transnational governance does not necessarily imply that postcolonial states have all been weakened. Rather, state repression against dissenting workers and forcible relocation of populations to make way for development projects, reconfigure the relationship between the state and its citizens. In Bangladesh's case, however, the economic interests of the politician-businessmen in charge of the state (Siddiqui and Uddin, 2016) may significantly impede its ability to play a catalytic role in transnational governance, and potentially jeopardise the effectiveness of the certification process. In their study, Reinecke and Ansari concentrated only on the private sector frame changes, highlighting the state's role as a catalyst in the process. The presence of a strong state-business nexus in Bangladesh allows us to explore if

(RMG) garment products for renowned global brands. At least 1,080 workers died in the accident, and making it the second deadliest industrial accident in history (Quelch and Rodqiguez, 2013).

2 https://www.bbc.co.uk/news/world-asia-22635409

3 https://www.ti-bangladesh.org/beta3/index.php/en/research-policy/96-fact-finding-studies/4608governance-in-readymade-garments-sector-review-of-progress-in-last-one-year-executive-summary-english 
the catalytic role of the state is an essential pre-condition for the responsibilisation framework to be effective.

Our study is primarily based on 24 semi-structured interviews conducted between 2015 to 2018 with RMG factory owners, workers, trade union leaders, various donor agencies operating in Bangladesh, as well as independent inspectors recruited by various MNCs to conduct social audits in factories. In addition, one of the authors also participated in a multi-stakeholder advisory consultation (MAC) meeting post-Rana plaza, programme enabling them to gain firsthand experience regarding the RMG owners' and managers' attitude towards governance issues in supply chains. We also collected extensive data from publicly available documents from 2006 to 2018 relating to the RMG sector in Bangladesh, including reports by international agencies, such as the Human Rights Commission, newspaper reports covering the Rana plaza incident, press releases made by the buyers, BGMEA and various policy makers in Bangladesh, blogs by human rights NGOs, companies, industry associations, official US congressional records, as well as legal documents, such as the Bangladesh Labour Law, and the tripartite agreement.

The rest of the paper is organised as follows. The following section provides an overview of the theoretical motivations for this paper. The research methods adopted are detailed in the following section. The subsequent empirical sections report the frame shifts that eventually allowed the private actors expressing interest in assuming responsibility to resolve governance issues in the RMG sector in Bangladesh, and the state's response to such interest. The discussion and conclusion section summarises the findings and highlights the contribution of this study.

\section{The role of framing in constructing corporate responsibility in supply chains}

Although the notion of framing has remained largely unexplored in the accounting literature, it is widely used in the sociology literature, especially in studying social movements and collective action (Benford and Snow, 2000). 'Framing' is defined as the process of selecting 'some aspects of a perceived reality and make them more salient in a communicating text, in such a way as to promote a particular problem definition, causal interpretation, moral evaluation, and/or treatment recommendation for the item described' (Entman, 1993, p. 52). 
One of the important features of framing is its ability to highlight some aspects of reality while omitting others. Reinecke and Ansari (2016) contend that typically, problems resulting in the Rana Plaza collapse, have no traceable cause. The divergent viewpoints amongst the stakeholder groups regarding the root causes of the problem makes it difficult to identify the main offending party. Consequently, such problems are often considered to be unsurmountable, and discourage collective actions (Gamson and Meyer, 1996). Reinecke and Ansari (2016) observe that framing offers a plausible solution to this problem. The notion of framing (Entman, 1993, p.52) essentially involves selection and salience-

\section{To frame is to select some aspects of a perceived reality and make them more salient in a communicating text, in such a way as to promote a particular problem definition, causal interpretation, moral evaluation, and/or treatment recommendation for the item described}

The process of framing involves highlighting and communicating some bits of an information so that it becomes more noticeable, meaningful and memorable to the audience. Snow and Benford (1988) identified three core-framing tasks: (1) diagnostic framing: a diagnosis of some event or aspects of social life as problematic and in need of alteration; (2) prognostic framing: a proposed solution to the diagnosed problem that specifies what needs to be done; and (3) motivational framing: a call to engage in corrective actions. Reinecke and Ansari (2016) draw on framing theory (Entman, 1993), to propose a theoretical model of the process of corporate responsibilisation of complex governance problems in supply chains. Their model requires private sector actors to go through three frame changes in the process of to breaking the status quo posed by the problems: construction of a responsibility frame; solidification of the responsibility frame, and corporate adoption of the responsibility frame. For each of these frame changes, Reinecke and Ansari (2016) proposes a number of mechanisms, or building blocks that would result in a corporate approach towards resolving the problems with governance. The three major frame changes and the associated mechanisms are briefly discussed below.

\subsection{Construction of a responsibility frame}

As discussed before, problems of governance in supply chains are often characterised by the presence of divergent viewpoints regarding the root cause of the problem, discouraging collective action. In order to construct a responsibility frame, and to mobilise a broader audience, it is therefore imperative to identify a plausible cause for the problem, offer a viable 
solution. Snow and Benford (1988) observe that while consensus regarding problem identification is often achieved, attributional consensus, where a causal linkage can be established between the problem and the perpetrator, is more difficult and requires certain degree of salience. Reinecke and Ansari (2016) propose that constructing a responsibility frame requires three specific mechanisms: the creation of a cognitive shortcut; establishment of a causal link between the targeted actor, and the problem, and the creation of an emotional connection to mobilise wider support for the issue. They note that in order to achieve attributional consensus, the apparently unsurmountable problem needs to be broken down into a number of sub-problems with a single or few targets that are handpicked. The creation of such a cognitive shortcut may create the impression of having more control over the issue (Fiske and Taylor, 1991), and eventually, create hope for a solution. Once the problem has been narrowed down, the next step is to identify a target. Typically, governance problems in supply chains are characterised by the presence of 'multiple villains' and it is not always easy to single out a target. In order to identify an effective solution, however, it is important to establish a causal linkage between the problem and the desired target (in most cases, the private actors), even if they are not the main culprit. Such a causal linkage can be manufactured through the use of symbols, stories and metaphors. The third frame change involves the creation of an emotional connection between the problem and the stakeholders so that the problem becomes a 'front-of-the-mind' issue (Reinecke and Ansari, 2016). The process might involve strategic deployment of symbolic 'moral shocks' that can be more effective than logics (Jasper, 2011).

\subsection{Solidification of responsibility frame}

Once the targeted actors are identified and a causal linkage is established between them and the problem, the process of solidification of responsibility begins in order to achieve the coreframing task of prognosis. Reincke and Ansari (2016) suggests two mechanisms at this stage, both involving an induction of social judgement on the targeted actor. The first of these frame shifts would be triggered by the induction of social judgments through third-party. Reinecke and Ansari (2016) observe that both forms of social judgement, shame and praise, can be powerful emotions of influencing behaviour. The fear of public shame, as well as the desire for public praise may force companies to rectify their behaviour, and reinforce the responsibility framework. The second mechanism at this stage would be triggered by inducing social judgments through self-disclosure, where companies voluntarily disclose non-financial information as regards to their approach towards tackling the problem. In recent times, there have been efforts to elevate the status of non-financial information (including disclosures 
regarding human rights violations) to the status of 'material' information (Eccles and Serafeim, 2013). In such a case, the burden for addressing the problem is actually shifted to corporations to actively demonstrate their responsibility in tackling the problem.

\subsection{Corporate assumption of a political role}

The third core task of motivational framing involves a shift from compliance towards actively co-authoring the responsibility frame. At this stage, companies are expected to demonstrate their commitment towards the problem by actively engaging with it. Reinecke and Ansari (2016) observe that some companies may have initially participated in the private governance regime due to strategic reasons. However, at this stage, companies are persuaded to take a political role by co-authoring the responsibilities frame. This could be achieved through dialogues and engagement with other important stakeholder groups, such as the government.

A key element in Reinecke and Ansari's (2016) model is the catalytic role played by the state. In recent times, the political CSR literature has claimed that globalisation and subsequent transnational governance process has led to diminished power of the state (Djelic and SahlinAndersson, 2006). In a recent study, however, Alamgir and Banerjee (2019) point out that globalisation and the subsequent emergence of transnational governance does not necessarily imply that postcolonial states have all been weakened. Rather, in certain areas of the economy the state has a very strong presence. State repression against dissenting workers, forcible relocation of populations to make way for development projects reconfigure the relationship between the state and its citizens. Also, Siddiqui and Uddin (2016) demonstrate that the presence of a strong state-business nexus may result in gross violation of human rights in global supply chains, resulting in large scale industrial accidents. In the case of Rana Plaza, the economic interests pursued by the politician-businessmen in charge of the state may significantly handicap its ability to play a catalytic role in transnational governance. This presents the context for this study.

\section{Research method}

\subsection{Data collection}


Following the Rana plaza incident, foreign governments mounted pressure on the BGMEA and the Bangladesh government to ensure proper working conditions in the RMG sector. To raise awareness regarding workers' rights in the RMG industry, a Europe-based human rights institute arranged a series of multi-stakeholder advisory consultation meetings (MAC) in Dhaka. Participants in the consultation events included owners and managers of RMG factories, representatives from the apex bodies, BGMEA, the Government of Bangladesh (GoB), various NGOs, human rights groups, researchers and international aid agencies operating in Bangladesh. One of the authors attended the consultation meeting and was actively involved in facilitating dialogues in different tables. Notably, such access to important stakeholders in the RMG sector is unique, given the sensitiveness of human rights issues, and provides a rich source of information for the purpose of this study. The author's participation in the MAC programme enabled them to gain first-hand experience regarding the RMG owners' and managers' attitude towards labour governance issues. The participation in the MAC meeting in 2014, and subsequent engagement with the RMG industry in Bangladesh providedx further access to RMG owners, including BGMEA leaders and labour union leaders. Between 2016 and 2018, we conducted 27 semi-structured interviews with participants and stakeholders in the RMG industry of Bangladesh. Interviews were conducted with medium and large factory owners, managers, labourers, as well as staff members of international organizations, such as ILO. We also interviewed a number of policy makers within the government. A list of the interviewees is provided in Table 1.

\section{$<$ Table 1 around here $>$}

Generally, the interviews focused on the post-Rana plaza regulatory environment in the RMG sector operates in Bangladesh and potential impact of the certification process on factory owners and the workers. Proceedings from the MAC meeting were used to identify the major issues affecting the sector, such as workers' safety, poor wages, and workers' voice. Interviews lasted one hour on average and were conducted in Bengali by one of the native-language speaking authors. Only three interviewees allowed data recording, indicating the sensitive nature of the data gathered. Transcribed data were sent to the interviewees for their approval. At this stage, the three interviewees from the GoB refused to give their permission to publish their interviews for this purpose of this study, bringing the total number of interviews down to 24. Interview data were complemented by archival data and personal observations in industry meetings. In addition, we collected extensive data from publicly available documents from 2006 to 2018 related to the RMG sector in Bangladesh, including reports by international 
agencies, such as the human rights commission, newspaper reports covering the Rana plaza incident, press releases made by the buyers, BGMEA and various policy makers in Bangladesh, blogs by human rights NGOs, companies, industry associations, official US congressional records, as well as legal documents, such as the Bangladesh Labour Law, and the tripartite agreement.

\subsection{Data analysis}

As discussed earlier, the problems in the RMG industry in Bangladesh are multi-faceted and complex. Our first task, therefore, was to identify a series of key events leading up to the collapse of the Rana plaza, as well as events following the accident. This is consistent with the event history database used in similar studies (Van de Ven and Poole, 2002). The key events are summarised in Figure 1.

\section{$<$ Figure 1 around here $>$}

For the purpose of data analysis, we adopted an exploratory flexible pattern matching design with nested template analysis (Sinkovics et al, 2019). Sinkovics (2018) note that whereas full pattern matching is used in explanation building and theory testing, flexible pattern matching is most suitable for exploration and theory building. In addition, flexible pattern matching allows for the emergence of new, unexpected dimensions, as well as the revision of the hypothesised relationships, and an extension of the theoretical framing. For the purpose of this paper, we use Reinecke and Ansari's (2016) responsibilities framework to investigate the private sector frame change. Therefore, the flexible pattern matching technique appears to be more relevant in our case.

Table 2 provides an overview of the template, containing the individual theoretical patterns, the corresponding operationalisations and the expected observational patterns. The latter are comparable to preliminary propositions that form part of our initial theorising (Sinkovics 2018). The first column indicates the three distinctive frame changes, as identified by Reinecke and Ansari's responsibilisation framework. The second column shows specific mechanisms, as identified by Reinecke and Ansari (2016) that trigger the multiple frame changes. The third column specifies the anticipated observational patterns we expected to find in the empirical data. Interview data was analysed using the propositions contained in the initial template, with 
the three core framing tasks- diagnostic framing, prognostic framing, and motivational framing, used as initial nodes. We found Reinecke and Ansari's (2016) specific framing mechanisms (for example, the creation of a cognitive shortcut, establishment of a causal linkage between the potential target and the cause; creating a moral shock, inducing third party social judgements, co-authorising responsibility) very useful for the purpose of coding and analysis of the interviews. We then used two separate templates to investigate the differences between the anticipated and actual patterns for the private sector. These are now discussed in the following sections.

\section{$<$ Table 2 around here $>$}

\section{The RMG sector in Bangladesh: Pre-Rana plaza status quo}

Although unsafe working conditions was the immediate cause of the Rana plaza collapse, the RMG sector in Bangladesh had long suffered from several economic and non-economic challenges. The presence of rampant corruption by government inspectors, and the government's failure to ensure building safety was reported in various international media (Time, 2013) ${ }^{4}$. The European Union (EU) identified political instability and labour governance as the two key non-economic factors threatening the future of the RMG industry in Bangladesh $^{5}$. The Bangladesh apparels industry is regarded as the cheapest in the world (New York Times, 2012) $)^{6}$, mostly due to meagre level of wages offered to the workers, as well as poor working conditions. Historically, RMG owners have been reluctant to allow the formation of trade unions. Attempts to formulate trade unions have frequently been thwarted by RMG owners through severe repression, dismissal, and assault by hired hooligans (Siddiqui and Uddin, 2016). There is evidence that repression of trade unions had often resulted in the disappearance or even death of their leaders ${ }^{7}$. Subsequently, there have been frequent violent street protests ${ }^{8}$. Siddiqui and Uddin (2016) report that the Government of Bangladesh (GoB) and the BGMEA had consistently adopted a policy of denial in response to labour unrests in the RMG sector. The Government's reluctance to raise the minimum wage was partly due to its attempts to keep Bangladesh the cheapest global outsourcing location for this industry

\footnotetext{
${ }^{4}$ http://world.time.com/2013/09/12/in-wake-of-rana-plaza-tragedy-bangladesh-garment-factory-inspections-floundering

${ }^{5} \mathrm{http}: / /$ www.fibre2fashion.com/news/apparel-news/newsdetails.aspx?news id=89668

${ }^{6} \mathrm{https} / /$ www.nytimes.com/2012/11/26/world/asia/bangladesh-fire-kills-more-than-100-and-injures-many.html

7 https://libcom.org/news/more-mayhem-cops-kill-again-garment-workers-rioting-continues-bangladesh28062009

${ }^{8} \mathrm{https} / / /$ libcom.org/news/more-strikes-and-riots-in-bangladesh-garment-workers-take-the-offensive-again-12102006
} 
(CNN, 2013). Media reports suggest that the foreign buyers, worried about the impact of labour unrest in the RMG sector, had repeatedly asked the GoB to reconsider the wage rate in this industry. In a meeting with the Prime Minister in 2012, the CEO of H\&M, a global retail brand that used Bangladesh as a supply chain, asked the GoB to review the wage rates-

'If a proper review system (of wages paid to the workers) is created and enforced, these revisions will help address the basic needs of the workers and bring greater stability to the market (H\&M, 2012)

However, despite such observations by foreign buyers, the RMG owners concentrated on reinforcing their ability to provide the cheapest outsourcing RMG location in the world, leaving the sector exposed to poor and unsafe working conditions. This resulted in frequent industrial accidents in the sector. For example, on $24^{\text {th }}$ November 2012, a deadly fire broke out in Tazreen Fashions, an RMG unit producing apparel for leading manufacturers such as Walmart and C\&A. At least 112 people were confirmed dead in the fire (The New York Times, 2012). Prior to Tazreen, 29 workers had died in the Hameem factory fire in 2010. In both cases, the government was accused of criminal negligence, having turned a blind eye to working conditions (Kernaghan, 2012). However, despite these allegations, the GoB and the BGMEA continued to pursue a strategy of denial, referring to the incident as 'an act of sabotage' (Reuters, 2012; Gomes, 2013). Siddiqui and Uddin (2016) note that the denial strategies pursued by the GoB and the BGMEA were perhaps based on their awareness of the fact that Bangladesh could provide the cheapest possible outsourcing location for the global RMG manufacturers, and hence remain attractive to large global brands, despite high profile incidents.

Overall, the pre-Rana plaza RMG sector in Bangladesh was characterised by the presence of several stakeholder groups with conflicting viewpoints, such as the private actors (the foreign brands and their local suppliers) who were willing to use Bangladesh as the cheapest possible destination for the production of the RMG, thus maximising their global profit; the BGMEA and the GoB, working together to protect the interest of the RMG factory owners; various trade unions and foreign agencies such as the ILO, trying to ensure workers' rights. A dominant coalition between the GoB and the BGMEA allowed various forms of labour exploitation to continue in the industry. Although the foreign buyers had time to raise concerns regarding the presence of poor wage rates and appalling working conditions in Bangladesh, their objections were not serious enough to compel the GoB to tackle the issue of modern slavery. Rather, the 
foreign buyers were happy with the ineffective system of inspection and compliance in the preRana plaza era, that allowed them to maximise their profits. This is akin to Reinecke and Ansari's (2016) observation of the existence of complex governance problems in supply chains.

The magnitude of the Rana plaza collapse, and the negative media publicity attached to it, however, resulted in the initiation of a strict certification regime in the RMG sector in Bangladesh. In what follows, we use Reinecke and Ansari's (2016) political responsibilisation framework to investigate whether this potential solution to governance problems in the RMG sector was achieved through a number of frame shifts. We note that one important element of Reinecke and Ansari's (2016) framework is the role of the state as a catalyst in the process of frame shifts. In the case of Bangladesh, the discussion presented above clearly suggests that the state is perhaps part of the problem. Therefore, for the frame-change approach to be effective in allowing the private sector to assume the responsibility in tackling the governance issues in the RMG industry in Bangladesh, the state needed to play either a neutral or a catalytic role in the process. This is now explored in the following sections.

\section{Private sector frame changes post Rana plaza}

In this section, we combine interview and archival evidence to identify the specific mechanisms that resulted in several frame shifts to allow the introduction of a private sector led certification regime in the RMG sector in Bangladesh post Rana plaza. As mentioned in section 3, we use a flexible pattern matching approach (Sinkovics et al, 2019) to compare the expected pattern with the actual outcome. Table 3 presents the initial and final templates for the private sector frame changes.

$<$ Table 3 around here $>$

\subsection{Accepting responsibility for labour governance in supply chains}

As discussed in section 5, the multifaceted and the complicated nature of the problem in the RMG sector in Bangladesh allowed all the stakeholder groups: the GoB, the BGMEA, RMG owners, and foreign buyers of apparels from Bangladesh to continue the status quo. The magnitude of the human rights disaster at the Rana plaza, however, triggered a more serious 
response from the international community. The widespread media coverage, containing disturbing pictures of the building collapse, resulted in widespread anger against the brands that used Bangladesh as a cheap production facility-

Brands were fully aware of the conditions at factories like Rana Plaza but continued business as usual, increasing orders and demanding lower prices. The brands knew that this flawed production model had led to countless accidents and deaths in Bangladesh's garment factories before the devastating collapse at Rana Plaza (The Guardian, 2015)

Major international media outlets urged the top brands to take a more responsible role in Bangladesh (The Economist, 2013) 9 by 'taking action, not walking away'10 (The Guardian, 2013). Disney, one of the major brands that decided to withdraw from Bangladesh after the Rana plaza collapse, attracted severe media criticism for 'abandoning responsibility towards workers it exploited' (The Guardian, May 16, 2013). However, rather that discussing the multifaceted nature of the problem, the world media concentrated mostly on building and fire safety as the root cause of the problem. As pointed out by Reinecke and Ansari (2016), the creation of such 'cognitive shortcuts' can provide an impression that the problem is not unsurmountable and helps identify a potential target.

Before the Rana plaza collapse, the local suppliers mostly monitored the building and fire safety issues by various forms of certification schemes. One interview respondent emphasised the ritualistic nature of such governance arrangement:

Before Rana plaza, we were only required to state that we comply with these standards. But the buyers were not serious regarding inspections, at that time we could hire local inspectors and get a certificate in exchange for money. We also had to bear the cost of such certification arrangements, so obviously we went for the cheapest possible provider (of such certification services) (Interview respondent 03, RMG manager)

Under such arrangements, two of the factories operating within the Rana plaza were certified as 'safe', revealing major failures in the pre-Rana plaza certification arrangements. The fact that the brands, despite being aware of poor building and fire safety conditions in Bangladesh, relied upon the local suppliers for such certification arrangements created a clear 'causal linkage' between the root cause of the problem and the identified 'culprits'- the foreign brands

\footnotetext{
${ }^{9} \mathrm{https}: / /$ www.economist.com/leaders/2013/05/04/disaster-at-rana-plaza

${ }^{10} \mathrm{https} / / /$ www.theguardian.com/sustainable-business/dhaka-factory-collapse-businesses-held-responsible
} 
using Bangladesh as their cheap outsourcing locations. As discussed before, the next step of the responsibilisation process involved achieving an emotional connectivity in order to mobilise wider support for this issue. At this stage, activists sometimes employed various 'moral shocks' that would 'arouse empathy, guilty and righteous anger' (Rao, 2008) so that the people could relate these issues with their everyday experiences. In Rana plaza's case, such moral shocks were effectively delivered by the mainstream world media, with headlines such as 'Is there blood in your shirts?' (Time, 2013a), and 'Do the clothes on our back leave blood on our hands?' (The Irish Times, 2013). In a 15-minute webcast titled 'The shirt on your back', The Guardian used several moving videos and pictures highlighting the human costs of the garments produced in Bangladesh (The Guardian, April 16, 2014). This had the potential, and possibly was done with the intention, to create an emotional connection between the end users of Bangladeshi RMG products and the identified root cause of the problem, and subsequently triggered collective action. In the USA, for example, college students organised vigils to put pressure on the brands to tackle the labour governance issues in Bangladesh-

Our universities have multi-million-dollar contracts with these large brands, so we need to use this strategic leverage right now in order to pressure these brands to sign ${ }^{11}$ (Student activist, USAS)

The emotional connectivity between the customers and the labour governance issues in Bangladesh appeared to have resulted in a frame change, with a number of brands accepting their responsibility for the poor working conditions in Bangladesh. For example, Primark, a highly profitable global apparel brand known for its cheap products, vowed to a review its compliance arrangements in Bangladesh-

Primark has been engaged for several years with NGOs and other retailers to review the Bangladeshi industry's approach to factory standards. Primark will push for this review to also include building integrity (The Telegraph, 2013).

Similar statements were issued by several other brands, such as H\&M, Matalan, and Bonmarche (The Telegraph, 2013). This is a major shift in the approach of private actors in confronting the governance failures in Bangladesh. Thus, in a sense, the sad case of the Rana plaza collapse helped perform three core framing tasks: diagnosis (identifying health and fire

\footnotetext{
${ }^{11}$ https://eu.usatoday.com/story/news/world/2013/10/25/student-activism-bangladesh/3188803/
} 
safety as the root cause); prognosis (establishing a causal linkage between the brands and the audit failures), and mobilisation (creating an emotional connection with the ultimate users of the garments by delivering moral shocks). Consequently, a responsibility framework for the private sector was created to allow a plausible solution to the acute governance problem existing in the Bangladeshi RMG industry. However, as proposed by Reincke and Ansari's (2016) responsibilisation framework, an effective solution to a complex problem requires two further frame shifts resulting in solidifications and adoption of the responsibilities frame. The following sections inspects whether such frame changes occurred in the post-Rana plaza period in Bangladesh.

\subsection{Solidifying responsibilities through the Alliance and Accord certification schemes}

As mentioned before, even before the Rana plaza collapse, the Bangladesh RMG industry was subject to frequent industrial accidents. Following a major fire incident that killed 21 workers in a RMG factory in 2010, the International Textile, Garment and Leatherworkers Federation (now known as the IndustriALL) started consultations with unions and major stakeholders in Bangladesh to formulate a set of proposal for improving building and fire safety (Clean Clothes Campaign, 2013). The GoB and the BGMEA, however, failed to join the consultation, perhaps indicating their disapproval of the development. The initiative finally received some attention from the GoB and the BGMEA in 2011, after a series of fire-related incidents in several RMG factories resulted in significant human casualties. In a meeting in April 2011, representatives from the BGMEA, various brands, NGOs, trade unions and the GoB discussed the need for a memorandum of understanding $(\mathrm{MoU})$ to establish a safety programme to prevent future fire related incidents (Clean Clothes Campaign, 2013). However, eventually, the MoU was not agreed due to lukewarm responses from the brands and the BGMEA. The collapse of the Rana plaza in, however, 2013 delivered a major impetus for the urgent implementation of the building and fire safety action plans (Clean Clothes Campaign, 2013). As the failure of major brands to sign the building and fire safety agreement received worldwide publicity, calls were made in the global media to boycott their products (The Huffington Post, 2013). In the USA, student activist groups used slogans such as 'shame on Walmart' for the global giant's failure to improve safety conditions in Bangladesh. This is akin to what Reinecke and Ansari (2016) refer to as 'induction of social judgements through third party exposure' (pp. 318). Prior literature has acknowledged the role of social judgements on the performance of companies 
through third party exposure (Bitektine, 2011; Tost, 2011). Vasi and King (2012) point out that the induction of such social judgements create higher risk to legitimacy as well as financial loss, and may result in a frame shift. In the case of Rana plaza, this frame-change mechanism appeared to be very effective- within three weeks of the collapse, more than 80 global brands, predominantly from Europe, signed the legally binding 'Accord for Fire and Building Safety in Bangladesh' (hereafter, Accord) with representatives from the BGMEA and the trade unions. When several major US brands refused to sign the agreement following the Rana plaza collapse, activists applied a strategy of naming and shaming. For example, activists were severe in their criticism of the Topshop, a global brand, for their unwillingness to sign the accord:

TopShop's bosses have got no excuse for not signing this agreement. With their bumper profits, they can easily afford a tiny fraction of that to make their supplier factories safe. Their failure to act and to work with other UK high street retailers to make these factories safe leaves thousands of workers' lives at risk. (War on Want, The Guardian, 2013c).

As a consequence of such induction of social judgements through third party exposure, another certification initiative called 'Alliance for Bangladesh Worker Safety' (hereafter, Alliance) was eventually signed by 29 major brands in North America (The Guardian, 2013b). Both Alliance and Accord initiatives would rely heavily on certification mechanisms to ensure fire and building safety, and had a limited time span of five years to accomplish their objectives. Unlike the pre-Rana plaza regulatory regime, these certification mechanisms would be directly monitored by the brands via Alliance and Accord. Hence, the introduction of Alliance and Accord certification regime represent a major frame shift in terms of solidifying the responsibilities towards tackling labour governance problems in the RMG sector in Bangladesh. Notably, several companies actually accepted the responsibility for ensuring building and fire safety in their factories in Bangladesh by mentioning that they were 'Signatory to the Accord on Fire and Building Safety in Bangladesh' (for example, Primark, 2014). To Reincke and Ansari, such self-disclosure is an important mechanism for strengthening the responsibilisation framework, as through such disclosure, the burden of proof' is shifted from the third parties (i.e. activists groups involved in naming and shaming) onto companies by making them responsible for 'knowing and showing' their social performance (pp. 318). This is consistent with the recent trend of using non-accounting information relating to corporate social and environmental performance, as well as human 
rights, to the forefront of disclosures presented to the investors (for example, McPhail and Ferguson, 2016; Humphrey, O’Dwyer and Unerman, 2017)

\subsection{Corporate political engagement via extension of the scope of Alliance and Accord inspections}

The third frame shift involves companies going beyond simply complying towards actively engaging with the problem and co-authoring the responsibility frame. Reinecke and Ansari (2016) observe that at this stage, actors start to change their strategy from following a safe path of acquiescence to assuming a more active, political role in tackling the problem. As discussed before, the pre-Rana plaza compliance arrangements relied upon the certifications provided by supplier-appointed auditors. Interviews with several factory managers, however, confirm significant change in such arrangements post-Rana plaza-

The inspectors appointed by the buyers (Alliance/Accord) are competent and serious about their work. Hence, we have to take a lot of preparations before they come. (respondent 17, RMG manager)

There are three types of manufactures in the RMG industry in Bangladesh: direct, indirect, and informal. After the Rana plaza incident, the direct manufactures, mostly owners of large, selfcontained RMG factories, have been subject to increased regulatory focus and media attention (NYU ,2015), and are regularly inspected by independent third-party inspectors under Alliance and Accord. However, in order to cope with large orders, the direct manufacturers sometimes outsource to other small factories. The factories located in the Rana plaza all fell in this category of 'indirect' manufacturers. Interview responses suggest that the Alliance and Accord inspectors also inspect these units, although the nature and frequency of such visits might differ significantly, depending on customer demands-

When we receive orders from large brands, they make sure that our subcontractors also have compliance arrangements. However, for other orders, we only recruit inspectors for subcontractors if the buyers specifically require it- these are expensive arrangements, you know (Interview respondent 14, RMG manager)

After the Rana plaza collapse, direct manufactures have acquired many of such indirect units so that proper compliance with Alliance and Accord's requirements can be ensured- 


\begin{abstract}
After Rana plaza, buyers want us to provide assurance that our subcontractors are also complying with fire and other safety requirements. This is sometimes difficult to ensure, as we do not run their factories. Now, we have bought a number of smaller factories who used to be our subcontractors, making compliance a bit easier although expensive! (Interview respondent 01: RMG owner, chairman of the board)
\end{abstract}

This is indicative of the willingness of the private actors to assume a more engaged role within the responsibilisation framework. Also, interviews reveal that although the Alliance and Accord inspection arrangements exclusively concentrated on ensuring compliance with building and fire safety requirements, some inspectors ask more probing questions on a broader range of issues, such as workers' wages-

Sometimes the inspectors asked if we receive the minimum wage, and we say yes. In fact, we do receive the minimum wage, and this is higher than before (pre-Rana plaza). (Interview respondent 15: operator, female)

Interview evidence suggests that the post-Rana plaza responsibilisation framework has resulted in improved working conditions for some workers. As suggested by a worker-

Things are so much better after (the post-Rana plaza initiatives). You should have seen (the working conditions) 4/5 years back- those were horrible. We are much better off now (Interview respondent 11: operator, male)

This is supported by media reports that state that by 2018,84 percent of the building and fire safety related problems that existed at the time of the Rana plaza collapse had been fixed (Financial Times, 2018).

The willingness of the brands to assume a more pro-active, political role was further confirmed in 2017, when IndustriAll initiated a 'new Accord' agreement proposing to extend the initial 5 -year term of the Accord governance regime by a further 3 years. This new agreement would extend the previous scope of Accord's inspection by putting 'greater emphasis on the right of workers to organize and join a union, recognizing worker empowerment is fundamental to assuring workplace safety' ${ }^{12}$. Reinceke and Ansari (2016) mention that a frame shift triggering the willingness to assume a political role can only be achieved through dialogues involving key multi-stakeholder groups. These dialogues between the trade unions and brands were facilitated

\footnotetext{
$12 \mathrm{http}$ //uniglobalunion.org/news/leading-fashion-brands-join-unions-sign-new-bangladesh-accord-fire-and-building-safety
} 
by various activist groups, including the IndustriAll and the Clean Clothes Campaign. In a jointly written media statement in 2017, the Clean Clothes Campaign (CCC), the International Labour Rights Forum (ILRF), Maquila Solidarity Network (MSN), Worker Rights Consortium (WRC) claimed that the Accord's robust inspections had resulted in a high remediation rate of 79 percent, as opposed to GoB's own remediation rate of only 20 percent. The article claimed that a further extension of the Accord was necessary in order to ensure that the safe working conditions continue for a longer period of time-

The purpose of the renewed Accord, which takes effect in May of 2018 when the current 2013 Accord expires, is to ensure that factories made safe under the Accord remain safe. At the same time, the new Accord will support improvements to Bangladesh's public regulatory regime, in order to strengthen and pass on this responsibility to the Bangladesh government at the end of those three years (The Daily Star, 2017)

The article also claimed that this plan was discussed with other major stakeholders, including the GoB and the BGMEA-

As was agreed to in meetings on October 19 between brand and trade union signatories to the Accord, the BGMEA, and the Bangladesh Ministers of Commerce and Labour, the Accord will continue this work until the local regulatory bodies meet a set of rigorous readiness conditions ((The Daily Star, 2017)

However, in July 2018, the GoB announced that Accord would only be allowed to operate in Bangladesh for six more months, indicating a major difference in opinion between the two key players in the RMG sector in Bangladesh: the state, and the foreign brands (The New Age, 2018). Essentially, this would result in ending the private regulatory regime that appeared to achieved some success in delivering better working conditions in the RMG sector in Bangladesh post Rana plaza.

One of the key elements of the ultimate success of Reinecke and Ansari's (2016) responsibilisation framework is the catalytic role of the state (Reinecke and Ansari 2016, pp. 323). Reinecke and Ansari (2016) uses the case of conflict minerals in Congo to demonstrate how the state can play a complimentary role by not trying to impose itself, but by mandating arrangements (such as self-reporting) that empowered civil society actors to hold corporations accountable. However, unlike the case of Congo, where there was no lack of willingness from the state to resolve the problem, the existence of a state-business nexus in the RMG sector 
(Siddiqui and Uddin, 2016) makes the GoB a vested interest group in the treatment of workers in the RMG. Therefore, in order for a meaningful solution, the state has to go through multiple frame-shifts in conjunction with the private sector. Although the GoB's decision to allow the Alliance and Accord inspections in 2013 could be indicative of such a frame change, the recent decision to deny an extension of the certification regime may suggest otherwise. In what follows, we examine the role of the GoB within this responsibilisation framework that would allow the private sector to assume a more political role in tackling governance issues in the RMG sector in Bangladesh.

\section{State's approach to the governance failures in the RMG sector}

Siddiqui and Uddin (2016) note that the presence of a collusion between the GoB and the BGMEA resulted in both these actors applying a consistent strategy of denial in response to any attempts to reform working conditions in the RMG sector in Bangladesh. Immediately after the Rana plaza collapse, a senior minister of the GoB blamed the opposition party for the building collapse (The Huffington Post, 2013). However, as the disturbing images of the Rana plaza rubble quickly circulated across the international media, the failure of the GoB to properly monitor working conditions was highlighted, making it a potential villain for the governance failures. Even before the Rana plaza collapse, various international agencies, such as the ILO was critical of GoB for its denial of legal rights for workers to democratically elect collective bargaining agents (ILO, 1995). However, due to BGMEA's strong opposition, the GoB refused to carry out any reforms to the Labour Law. After the Rana plaza collapse, the US government suspended the generalised system of preference (GSP) facility to Bangladesh, accusing the GoB of its failure to amend the Labour Law to ensure workers' rights (USTR, 2013). This resulted in GoB agreeing to amend the Labour Act (GoB, 2006) on 22 July 2013, four months after the Rana plaza collapse. The amendments conform more closely to international labour standards, namely the strengthening of fundamental rights at work, particularly regarding certain aspects of freedom of association and collective bargaining, and improved occupational safety and health standards. In order to ensure proper working conditions in factories that fell outside the purview of Alliance and Accord certifications, the GoB also signed the integrated National Tripartite Plan of Action (NTPA) with representatives from local employers' and workers' organizations in the RMG sector in 2013. Notably, the NTPA was originally proposed by the ILO after the Tazreen fire accident in 2012 (GoB, 
$2013)^{13}$. However, the plan of action was only approved by the GoB after the Rana Plaza collapse, perhaps suggesting a response to a severe crisis of legitimacy. Like the Alliance and Accord initiatives, the NTPA contained a detailed guideline regarding building and fire safety certification arrangements. However, unlike the private governance regime, the certifications under the NTPA would be carried out by the Government inspectors. The scope of government inspection was also much wider: whereas Alliance and Accord compliance auditors only had the mandate to ensure building and fire safety, the GoB inspectors would ensure compliance with the Labour Law, as well as the NTPA. It is worth noting that prior to the Rana Plaza collapse, the GoB inspectors used to carry out inspections to ensure compliance with the Bangladesh Labour Law (2006). The quality of such inspection and their susceptibility to corruption is well documented:

[The inspections] are nothing to us — the teams come for an hour, they take some free shirts, and then they go away, (Time, 2013b)

One interview respondent pointed out that the activities of this department was severely constrained by availability of resources, indicating the GoB's lack of attention to this department-

There was one Chief Inspector of Factories/Inspector General. (Equivalent to Assistant Secretary status). Let me now tell you about the status of this department before Rana Plaza. This department had only 78 employees for entire Bangladesh. Only 78 people were there to look after the issues of implementation of labour law, employee security, building safety, worker health in all the factories, not only for the RMG. Can you imagine? If only 78 people are there for the whole country and if they go on inspection in one factory, the time they will take to come back to the same factory will be more than a year. This was the overall picture (Interview respondent 2: RMG factory owner)

Following the collapse of Rana Plaza, the GoB recruited an additional 200 labour inspectors, indicating its commitment to improve working conditions in factories (ILO, 2013) ${ }^{14}$. Several interview respondents, however, expressed their dissatisfaction over the nature of the government inspections. Significantly, the corrupt nature of the government-appointed labour

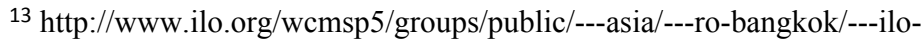
dhaka/documents/genericdocument/wcms_209285.pdf

${ }^{14} \mathrm{http}$ ://ilo.org/dhaka/Informationresources/Publicinformation/Pressreleases/WCMS_346612/lang-en/index.htm
} 
inspectors also appeared to be a major problem for compliance with the NTPA and the revised Bangladesh Labour Law -

The government inspectors come here for money. If you pay them, they are happy to sign off whatever you are asking for, and our buyers are aware of this' (Interview respondent 04: RMG managing director)

Several respondents also accused the government-appointed labour inspectors of harassment-

\begin{abstract}
After the Rana plaza incident, government inspectors used to come and ask for money. If we refused to pay, they threatened to closed down the premises (Interview respondent 02, RMG managing director and owner)
\end{abstract}

It also appears that some of the ILO-sponsored initiatives aimed at enhancing the capacity of the government inspections have been rather counter-productive-

The government inspectors who go for inspection in the factories, they ask for 'envelopes' while they are visiting. Recently, ILO provided them with a motorcycle so that they can access the place of the accident quickly. But they are using it in a different way. Previously, they could only visit 2 factories and now they can visit 5 factories per day by using the motorcycle and get 5 'envelopes'. Their income increased. (Interview respondent 17: $R M G$ factory manager)

Overall, although the Rana plaza collapse triggered few regulatory interventions from the GoB, the GoB's activities post-Rana plaza, especially its inability to curb corruption in government departments and ensure compliance with the Labour law, raises doubts regarding the seriousness of the GoB in achieving these reforms. It is possible that the GoB's half-hearted regulatory intervention following the Rana plaza collapse might just have been a temporary strategy in response to a crisis of legitimacy created by the Rana plaza collapse. Indeed, several recent events relating to GoB's response to the extension of the private sector regulatory regime raise serious questions regarding the role of the state within the responsibilisation framework. Contrary to Reinceke and Ansari's (2016) hypotheses, the hybrid forms of governance that emerged post Rana Plaza appear to have destabilized.

As discussed in section 5.3, in 2018 the Accord sought an extension of its initial term of five years in order to help build the capacity of the GoB to develop more effective compliance audit arrangements. Indeed, the evidence presented above clearly demonstrates that despite the regulatory interventions made by the GoB after the Rana plaza collapse, the state of the 
government certification arrangements remained far from satisfactory. This perhaps prompted the Accord and Alliance inspectors to sometimes operate beyond their mandate, and ask questions regarding important issues, such as worker's voice. However, the RMG owners appeared to resent such attempts by the Alliance and Accord inspectors to assume a political role:

The mandate on which Alliance and Accord came to BD, that is the safety concern, is no longer there. Now they are mobilizing the workers for trade union formation. Please read the clause included in the NTPA. It is written in the NTPA, that these organizations should work under the supervision and guidance of ministry of labour and employment. But they are not following this. Alliance and Accord have recently shut down two factories for violation (of safety standards). This is the government's job. The job of the Accord was to declare the number of factories being audited along with the list of concerns identified so that the government can take necessary initiatives (Interview respondent 06: $R M G$ owner)

This is consistent with Scherer and Palazzo (2011) who, in their seminal research on political CSR, point out that many businesses assume social and political responsibilities that go beyond legal requirements in order to fill the regulatory vacuum Notably, the RMG owners have traditionally opposed any attempts to form trade unions in the RMG sector. Therefore, it is rather unsurprising that the RMG owners in Bangladesh would generally opposed any extension of the terms of the legally binding Accord, allowing private actors to assume a more pro-active political role. The presence of a strong state-business nexus resulted in such a sentiment was also reflected in the activities of the GoB, with several Ministers denouncing the need for extension of private governance regime in the RMG sector in Bangladesh:

Bangladesh is capable to take over the responsibility of factory remediation...Accord and Alliance will leave Bangladesh after the six-month transition period on December 7 and then we will take over the responsibility of factory remediation and inspection (Commerce Minister, GoB, The New Age, July 28, 2018).

And-

I challenge that no Rana Plaza-like incident will take place in future in the country.... and the country's readymade garment sector no longer required Accord and Alliance as we have made significant progress in strengthening the capacity of the Department of Inspection for Factories and Establishments (State Minister for Labour, GoB, as reported in The New Age, 2018) 
However, private sector actors, and various international bodies, including foreign governments asked the GoB to re-assess their position on the new Accord (The Financial Express, 2018) ${ }^{15}$. On July 27, 2018, upon discussions with representatives from EU, US and Canadian governments, ILO and its signatory brands, Accord issued a statement urging the GoB to ensure that its operations in Bangladesh could continue. The statement observed that any premature shut down of the Accord would leave workers in unsafe circumstances and eventually jeopardize the brands' ability to source from a safe industry in Bangladesh. The Accord further observed that although the RMG industry has gone through significant reforms post Rana plaza, a lot remained to be accomplished-

In the last 5 years, the Accord has delivered a robust, high quality, transparent, inclusive system, and it has made substantial progress to achieve the safety of workers in Bangladesh's most important export industry. But the work is not yet completed and the national structure, notwithstanding assertions to the contrary, is not yet prepared to credibly take over the work of the Accord (Accord, 2018)

Interview respondents representing the civil society were widely supportive of Accord's intentions to continue in Bangladesh. A representative from the GIZ, a German government sponsored international development agency, echoed Accord's views regarding the consequences of a premature withdrawal from Accord-

Obviously, there has been a lot of improvements in safety conditions post-Rana plaza. However, the government is still far away from developing capacity to monitor compliance in all RMG factories in Bangladesh. The extended presence of Accord and Alliance in Bangladesh would allow further transfer of knowledge between the (Alliance and Accord and GoB) inspectors. Thus, GoB inspectors could learn a lot from the presence of private sector inspectors in the industry' (Respondent 24, GIZ)

However, so far the GoB has indicated no intention of allowing the private sector actors to take a more responsible role in ensuring governance in the RMG sector in Bangladesh.

\section{Discussion and conclusion}

\footnotetext{
15 https://thefinancialexpress.com.bd/trade/global-brands-band-together-against-accord-wind-down1533354243
} 
The objective of this paper is to explore the emergence of private sector responsibilisation for the governance failures post Rana Plaza. As mentioned in this paper, while social and environmental accounting literature have focused in exploring the procedural nature of the certification process (for example, Boiral, 2013), understanding how agents assume responsibility for these process in the first place remains relatively unexplored, as does the conflicts that can arise as multiple actors, with different interests respond with new regulatory practices. We apply Reinecke and Ansari’s (2016) responsibilisation framework to investigate responses to tackling governance issues in the RMG sector in Bangladesh post Rana Plaza. Reincke and Ansari (2016) use the case of conflict minerals in the Republic of Congo to demonstrate how the state can play a complimentary role by not trying to impose itself, but by mandating arrangements that empowered civil society actors to hold corporations accountable. However, in the case of Congo, although the state was willing to engage with the complex problem, it did not possess the regulatory authority to tackle the issue due to its transnational character. In Bangladesh's case, however, the existence of state-business nexus in the RMG sector (Siddiqui and Uddin, 2016) makes the state a vested interest group. The economic interests pursued by the politician-businessmen in charge of the state may significantly handicap its ability to play a catalytic role in transnational governance, and potentially jeopardise the effectiveness of the certification process. Hence, the use of Rana Plaza as the research site for this study provides us with the opportunity to further explore Reinecke and Ansari's (2016) assertion that the state can play a catalytic role in private sector engagement in tackling the governance problems inherent in supply chains.

Our analysis of events leading up to the Rana plaza collapse reveal that the tragic incident of Rana plaza collapse was an outcome of a significant governance failure. The multifaceted nature of the problem, combined with the presence of a strong-state business nexus, and the MNC's quest for profit maximisation, resulted in no particular state or non-state actor taking responsibility for governance of the sector. The magnitude of the Rana plaza collapse, and the negative media publicity attached to it appeared to have triggered several frame-shifts, resulting in the private actors willing to assume a more political role in taking responsibility for governance of this sector. Using Reincke and Ansari's (2016) responsibilisation framework, we identify several mechanisms through which such frame change was achieved. Interview responses suggest that overall, such private actor frame shifts led to improvements in working conditions in the RMG sector in Bangladesh, justifying the effectiveness of the responsibilisation framework. However, the refusal of the Bangladesh government to extend 
the tenure of the private governance regime, and allow the private actors to take on a more political role, created severe doubts regarding the role of the state within the process.

Our analysis of the role of the state revealed that the Rana plaza collapse triggered a number of regulatory interventions from the state. In a number of issues (for example, workers' right to formulate trade unions), the state retracted from its denial mode to initiate legal reforms. However, unlike the private sector, the state's activities post-Rana plaza, especially its inability to curb corruption in government departments and ensure compliance with the Labour Law, raise serious doubts regarding the seriousness of the $\mathrm{GoB}$ in achieving these reforms. Also, our analysis of recent developments reported in the media suggest that the state has been active in blocking any extension of the scope and time frame of the Alliance-Accord led social audit regime. Our long term analysis, appears to indicate that the regulatory interventions post Rana Plaza just have been a temporary strategy adopted by the GoB to ensure survival of the RMG sector in Bangladesh. Overall, our research suggests the need for further theoretical developments in our understanding of how contemporary processes of state responsibilisation work. It appears that in a context where the state is a major actor within the problem, its ability to play the role of a catalyst, allowing the private sector social audits regime to take effect, remains questionable.

We make several important empirical and theoretical contributions to the social and environmental accounting literature. As mentioned before, accounting research in this area has mostly investigated the legitimacy and reputation building aspects of the social audit process [Simnett et al. 2009, O’Dwyer et al. 2011; Boiral and Gendron (2011); Koukau, Boiral and Gendron (2013)], and the antecedent aspects of how responsibility for certification arises has remained largely unexplored. Within the accounting literature, there has been limited attempts in studying the social process of constructing responsibility that would eventually make the corporations more serious in tackling labour governance problems in supply chains, rather than superficial engagement with the topic for the purpose of legitimacy. Previous literature (for example, Burritt and Schaltegger, 2014) has also highlighted the importance of broadening the scope of accounting and measurement to support the sustainability agenda in production and supply chains. Burritt and Schaltegger (2010) observe that the aim of sustainability accounting within a multi-tiered supply chain should be to provide support to the management to overcome various social and economic trade-offs, and to ensure a win-win situation for all the stakeholders. Our analysis reveals that by broadening the scope of sustainability accounting and assurance process to include issues such as worker's wages and working conditions, social 
auditors can play a meaningful role in triggering collective actions that can eventually lead to private governance responsibilisation in global supply chains.

Adoption of Reinecke and Anasari's responsibilisation framework allows us to extend previous studies (for example, Scherer and Palazzo, 2011) exploring the political role of the MNCs in supply chains. Previous literature has not only identified the unsustainable social and environmental practices in developing countries (Burritt et al, 2018), but also acknowledged the capability of MNCs in improving working conditions via various employment and community programmes (Malovics et al, 2008). Our analysis of events post the Rana Plaza collapse suggests that the political involvement of the MNCs via CSR programmes can trigger a meaningful change in working conditions in supply chains. However, whereas Reinecke and Ansari (2016) concentrated on private sector frame changes, and assumed a catalytic role of the state, the use of the Bangladesh RMG sector as a research site allowed us to explore the efficacy of responsibilisation frameworks within a context characterised by the presence of a strong state-business nexus which would significantly limit the state's capacity to act as a catalyst. Our analysis suggests that in such a context, the sustained effectiveness of certification audits, achieved through a private sector frame change, would be significantly affected due to the state's active business interest on the issue. Thus, we extend Reinecke and Ansari's(2016) responsibilisation framework by suggesting that for a frame change approach to be effective in this context, the catalytic role of the state is an essential pre-requisite. In a recent paper, Islam et al ( 2018) emphasised the need for some form of surrogate (government, non-governmental organisations or media) intervention to make the state more proactive in making certification arrangements in supply chains more effective. Also, previous research in Bangladesh (for example, Siddiqui, 2001) have emphasised on the need for some kind of intervention to make the state more accountable for its governance failures. Our analysis suggests that such an intervention may be useful for ensuring the effectiveness of responsibilisation processes in constructing corporate social responsibility. 


\section{References}

Abbott, K., and Snidal, D., (2013), "Taking responsive regulation transnational: Strategies for international organizations", Regulation and Governance 7(1), pp. 95-113.

Accord (2018), "Accord statement on $4^{\text {th }}$ high level meeting of the Bangladesh sustainability compact", Bangladesh Accord, available at: https://bangladeshaccord.org/bn/2018/07/27/accord-statement-on4th-high-level-meeting-of-the-bangladesh-sustainability-compact/ (accessed on May 1, 2019).

Alamgir, F. and Banerjee, S.B. (2019), "Contested compliance regimes in global production networks: insights from Bangladesh garments industry”, Human Relations 72(2), pp. 272-97.

Barrientos, S. and Smith, S., (2007), "Do workers benefit from ethical trade? Assessing codes of labour practice in global production systems", Third World Quarterly 28 (4), pp. 713-729.

Bebbington, J. and Laranga, C. (2013), "Accounting and sustainable development: an exploration", Accounting, Organizations and Society 39, pp. 395-413.

Bernstein, S., and Cashore, B., (2007). "Can Non-State Global Governance Be Legitimate? An Analytical Framework", Regulation and Governance 1, pp. 347-371.

Bitektine, A. (2011), "Toward a theory of social judgments of organizations: the case of legitimacy, reputation, and status", Academy of Management Review 36, pp. 151-79.

Boiral, O. and Gendron, Y. (2011), "Sustainable development and certification practices: lessons learned and prospects", Business Strategy and the Environment, Vol. 20 No. 5, pp. 331-347.

Boiral,O., (2013), "Sustainability reports as simulacra? A counter-account of A and A+ GRI reports", Accounting, Auditing \& Accountability Journal Vol. 26 Issue: 7, pp.1036-1071.

Burritt, R. L., Christ, K. L., Rammal, H. G., and Schaltegger, S. (2018). Multinational enterprise strategies for addressing sustainability: The need for consolidation. Journal of Business Ethics, 1-22.

Burritt, R. and Schaltegger, S. (2010). Sustainability accounting and reporting: fad or trend? Accounting, Auditing and Accountability Journal 23(7), 829-46.

Burritt, R. and Schaltegger, S. (2014). Accounting towards sustainability in production and supply chains. The British Accounting Review 46, 327-43.

Clean Clothes Campaign (2013), "Global support for Bangladesh factory safety surpasses 1 million", May 1, available at: https://cleanclothes.org/news/2013/05/10/global-support-for-bangladesh-factorysafety-surpasses-one-million (accessed on May 1, 2019).

CNN (2013), "Prime Minister says Bangladesh is reforming its garment industry", Cable News Network, available at: https://edition.cnn.com/2013/05/02/world/asia/bangladesh-buildingcollapse/index.html (accessed on May 1, 2019)

Darnall, N., Seol, I., and Sarkis, J. (2009), "Perceived stakeholder influences and organizations' use of environmental audits", Accounting, Organizations and Society, 34 (2), pp. 170-187.

Deegan, C., Cooper, B.J., and Shelly, M., (2006), “An investigation of TBL report assurance statements: UK and European evidence”, Managerial Auditing Journal 21 (4), pp. 329-371. 
Djelic, M.-L., and Sahlin-Andersson, K. (Eds) (2006), "Transnational Governance”, Institutional Dynamics of Regulation. Cambridge: Cambridge University Press.

Edgley, C.R., Jones, M.J., and Solomon, J.F., (2010), "Stakeholder inclusivity in social and environmental report assurance", Accounting, Auditing and Accountability Journal, 23 (4), pp. 532557.

Elad, C., (2001), "Auditing and governance in the forestry industry: between protest and professionalism", Critical Perspectives on Accounting 12 (5), pp. 647-671.

Entman, R. M. (1993), "Framing: toward clarification of a fractured paradigm", Journal of Communication 43, pp. 51-58.

Esbenshade, J. (2001), "The social accountability contract: Private monitoring from Los Angeles to the global apparel industry", Labour Studies Journal 26(1), 98-120.

Ferraro, F., Etzion, D. and Gehman, J. (2015), "Tackling grand challenges pragmatically: robust action Revisited”, .Organization Studies 36, pp 363-90.

Financial Times (2018), "Rana Plaza five years on- safety is greater but not guaranteed", April 24, available at: https://www.ft.com/content/7ec413ec-46e6-11e8-8ee8-cae73aab7ccb (accessed on May 1, 2019)

Fiske, S. T. and Taylor, S. E., (1991), "Social Cognition”, New York: McGraw-Hill Book Company.

Fransen, L., and Burgoon, B., (2013), "Global Labour-Standards Advocacy by European Civil Society Organizations: Trends and Developments”, British Journal of Industrial Relations 53(2), pp. 204-30.

Frynas, J. G., and Stephens, S. (2015), "Political corporate social responsibility: Reviewing theories and setting new agendas", International Journal of Management Reviews, Vol. 17, No.4, pp. 483-509.

Gamson, W. A. and Meyer, D. S. (1996), "Framing political opportunity", in McAdam, D., McCarthy, J., D., and Zald, M. N. (Eds), 'Comparative Perspectives on Social Movement', Cambridge: Cambridge University Press, 275-90.

Gendron, Y., Cooper, D.J., and Townley, B. (2007), "The construction of auditing expertise in measuring government Performance", Accounting, Organizations and Society 32, pp. 101-129.

GoB (2006), "Bangladesh Labour Act", Government of Bangladesh.

GoB (2013), "Bangladesh Labour (amendment) Act”, Government of Bangladesh.

GoB(2015), "Bangladesh Labour Rules", Government of Bangladesh, available at: http://dife.portal.gov.bd/sites/default/files/files/dife.portal.gov.bd/page/5cf00958 c15f_43d4_b0 30_1c4a1a1502ad/Labour\%20Rules\%202015.pdf

Goffman, E. (1974), "Frame Analysis: An Essay on the Organization of Experience”, London: Harper \& Row.

Gomes, W. (2013), "Reason and responsibility: the Rana plaza collapse", Open democracy, downloaded from https://www.opendemocracy.net/opensecurity/william-gomes/reason-andresponsibility-rana-plaza-collapse

Gray, R., (2000), "Current developments and trends in social and environmental auditing, reporting and attestation: a review and comment", International Journal of Auditing 4, pp. 247-68. 
H\&M (2012), "Meeting between the CEO of H\&M and the Prime Minister of Bangladesh", H\&M press release, available at: https://about.hm.com/en/media/news/meeting-between-hm-and-primeminister-of-Bangladesh.html (accessed on May 1, 2019)

HRW (2016), "Bangladesh: garments workers union rights bleak", April 21, available at: https://www.hrw.org/news/2016/04/21/bangladesh-garment-workers-union-rights-bleak (accessed on May 1, 2019).

HRW, (2012), "Letter to Prime Minister Sheikh Hasina Re. Wazed Killing of Aminul Islam, Bangladesh Center for Worker Solidarity", Human Rights Watch, New York, NY, available at: http://bdnews24.com/politics/2006/07/09/bhuiyan-rejects-tib-report-on-corruption-demandsimmediate-withdrawal.

Humphrey, C., O'Dwyer, B. and Unerman, J. (2017), "Re-thoerising the configuration of organisational fields: the IIRC and the pursuit of 'enlightened' reporting", Accounting and Business Research 47(1), pp. 30-63.

ILO, (1995), “Case no. 1862: Bangladesh", International Labour Organisation, Geneva. www.ilo.org/dyn/normlex/en/f?p=1000:50001:0::NO::P50001_COMPLAINT_FIE_ID: 2896790:NO.

ILO, (1995), “Case no. 1862: Bangladesh". International Labour Organisation, Geneva, www.ilo.org/dyn/normlex/en/f?p=1000:50001:0::NO::P50001_COMPLAINT_FIE_ID:2896790: $\underline{\mathrm{NO}}$

Islam, M.I., Deegan, C. and Gray, R., (2018). "Social compliance audits and multinational corporation supply chain: evidence from a study of the rituals of social audits", Accounting and Business Research 48(2), pp. 190-224.

Jamali, D. (2010). The CSR of MNC subsidiaries in developing countries: Global, local, substantive or diluted? Journal of Business Ethics, 93(2), 181-200.

Jasper, J. M. (2011), "Emotions and social movements: twenty years of theory and research", Annual Review of Sociology 37, pp. 285-303.

Justice, D. (2001). The new codes of conduct and the social partners. International Confederation of Free Trade Unions. Retrieved from http://www.icftu.org/

Kernaghan, C., (2012), "Criminal negligence leads to tragedy: at the Tazreen factory in Bangladesh", Institute for Global Labour and Human Rights, Pittsburgh, USA.

Kouakou, D., Boiral, O. and Gendron, Y. (2013), "ISO auditing and the construction of trust in auditor independence", Accounting, Auditing \& Accountability Journal 26(8), pp.1279-1305.

Liubicic, R. (1998), "Corporate codes of conduct and product labeling schemes: The limits and possibilities of promoting international labor rights through private initiatives", Law and Policy in International Business 30(1), pp. 111-58.

McPhail, K. and McKernan, J. (2011), “Accounting for human rights: an overview and introduction", Critical Perspectives on Accounting, Vol. 22 No. 8, pp. 733-737. 
Málovics, G., Nagypál N., and Kraus, S. (2008). The role of corporate social responsibility in strong sustainability. The Journal of Socio-Economics, 37(3), 907-918.

NYU (2015), "Beyond the tip of the iceberg: Bangladesh's forgotten apparel workers", Centre for Business and Human Rights, New York University, New York. http://people.stern.nyu.edu/twadhwa/bangladesh/downloads/beyond the tip of the iceberg report.p $\underline{\mathrm{df}}$

O’Dwyer, B. and Owen, D.,(2005), “Assurance report practice in environmental, social and sustainability reporting: perspectives of stakeholders in Ireland", British Accounting Review 37 (2), pp. 205-229.

O’Dwyer, B., Owen, D., and Unerman, J., (2011), "Seeking legitimacy for new assurance forms: the case of sustainability assurance", Accounting, Organizations and Society 36 (1), pp. 31-52.

O’Rouke, D. (2006), "Multi-stakeholder regulation: Privatizing or socialising global labor standards?", World Development 34(5), pp. 899-918.

Owen, D., (2007), “Assurance practice in sustainability reporting”, In: J. Unerman, B. O’Dwyer, and J. Bebbington, eds. 'Sustainability Accounting and Accountability'. Routledge, 168-183.

Owen, D.L., Swift, T.A., Humphrey, C., and Bowerman, M., (2000), "The new social audits: accountability, management capture or the agenda of social champions?", European Accounting Review 9 (1), pp. 81-98.

Primark (2014), "Statement from Primark on the anniversary of Rana plaza", April 23, available at: https://www.primark.com/en-ie/our-ethics/newsroom/2014/statement-from-primark-on-theanniversary-of-rana-plaza (accessed on May 1, 2019).

Quelch, J.A. and Rodriguez, M.L. (2013), "Rana Plaza: workplace safety in Bangladesh" Harvard Business School Case 514-034.

Rao, H. (2008), "Market rebels: how activists make or break radical innovations", Princeton, NJ: Princeton University Press.

Reinecke, J. and Ansari, S. (2016), "Taming wicked problems: the role of framing in the construction of corporate social responsibility”, Journal of Management Studies 53(3), pp. 299-329.

Reinecke, J. and Donaghey, J., (2015). “After Rana Plaza: building coalitional power for labour rights between unions and (consumption based) social movement organisers", Organization 22 (5), pp. 720 40.

Reinicke, W. (1998), “Global public policy: Governing without government?", Washington, DC: Brookings Institution Press.

Reuters (2012), "Bangladesh mourns, calls factory fire 'an act of subotage' ", November 27, available at: www.reuters.com/article/2012/11/27/us-bangladesh-fire (accessed May 1, 2019).

Rodriguez-Garavito, C. (2005), "Global governance and labor rights: Codes of conduct and antisweatshop struggles in global apparel factories in Mexico and Guatemala", Politics \& Society 33(2), pp. 203-333.

Scherer, A. G. and Palazzo, G. (2011). 'The new political role of business in a globalized world: a review of a new perspective on CSR and its implications for the firm, governance, and democracy'. Journal of Management Studies, 48, 899-931. 
Scherer, A. G., Palazzo, G. and Seidl, D. (2013). "Managing legitimacy in complex and heterogeneous environments: sustainable development in a globalized world"', Journal of Management Studies 50, pp 259-84.

Siddiqui, J. (2001), "Environmental non-accountability in Bangladesh? The striking case of the Magurchara gas field disaster", Social and Environmental Accountability Journal 21(2), pp. 12-13.

Siddiqui, J. and Uddin, S. (2016), "Human rights disasters, corporate accountability and the state: lessons learned from Rana Plaza", Accounting, Auditing and Accountability Journal 29(4), pp. 679704.

Silva-Castaneda, L., (2012), "A forest of evidence: third-party certification and multiple forms of proof - a case study of oil palm plantations in Indonesia", Agriculture and Human Values 29, pp. 361-370.

Simnett, R., Vanstraelen, A., and Chua, W. F. (2009), "Assurance on sustainability reports: an international comparison", Accounting Review, 84 (3), pp. 937-967.

Sinkovics, N. (2018), "Pattern matching in qualitative analysis" in Cassell, C.C., Cunliffe, A. and Grandy, G. (Eds), "The SAGE Handbook of Qualitative Business and Management Research Methods: Methods and Challenges, Sage publishers.

Sinkovics, N., Hoque, S.F., and Sinkovics, R.R., (2016), "Rana Plaza collapse aftermath: are CSR compliance and auditing pressures effective?", Accounting, Auditing \& Accountability Journal 29 (4), pp. 617-649.

Sinkovics, N., Choksy, U.S, Sinkovics, R.R., and Mudambi, R. (2019), "Knowledge connectivity in an adverse context: global value chains and Pakistani offshore service providers, Management International Review (2019) 59:131-170

Snow, D. A. and Benford, R. D. (1988), "Ideology, frame resonance, and participant mobilization", International Social Movement Research 1, pp. 197-217.

Soundararajan, V., Khan, Z. and Tarba, S.Y. (2018), "Beyond brokering: sourcing agents, boundary work and working conditions in global supply chains", Human Relations 71(4), pp. 481-509.

The Daily Star (2010), "RMG protesters return to work", December 14, available at: https://www.thedailystar.net/news-detail-165987 (accessed on May 1, 2019).

The Daily Star (2017), "Why the Accord will be here until 2021", November 15, available at: https://www.thedailystar.net/opinion/perspective/why-the-accord-will-be-here-until-2021-1491145 (accessed on May 1, 2019).

The Guardian (2013a), "Eight top fashion retailers fail to sign Bangladesh safety accord", May 8, available at: https://www.theguardian.com/business/2013/may/14/fashion-retailers-fail-to-signbangladesh-accord (accessed on May 1, 2019).

The Guardian (2013b), "Gap spearheads new alliance for Bangladeshi workers' safety", July 11, available at: https://www.theguardian.com/sustainable-business/gap-alliance-bangladeshi-workersafety (accessed on May 1, 2019).

The Guardian (2013c), “Topshop tycoon attacked for refusal to sign Bangladesh safety deal”, July 23, available at: https://www.theguardian.com/fashion/2013/jul/23/topshop-philip-green-safety-dealbangladesh (accessed on May 1, 2019). 
The Guardian (2013d), "Fashion chains sign accord to help finance safety in Bangladesh factories", May 13, available at: https:/www.theguardian.com/world/2013/may/13/fashionchain-finance-safety-bangladesh-factories (accessed on May 1, 2019).

The Guardian (2014), "The shirt on your back", April 16, available at: https://www.theguardian.com/world/ng-interactive/2014/apr/bangladesh-shirt-on-your-back (accessed on May 1, 2019).

The Guardian (2015), "Rana Plaza: are fashion brands responsible for those they don't directly employ?", April 10, available at: https://www.theguardian.com/sustainable-business/sustainablefashion-blog/2015/apr/10/rana-plaza-are-fashion-brands-responsible-for-those-they-dont-directlyemploy (accessed on May 1, 2019).

The Huffington Post (2013), "Bangladesh factory collapse: should you boycott Primark over workers' rights?", May 6, available at: https://www.huffingtonpost.co.uk/2013/05/02/primark-boycottbangladesh_n 3201576.html (accessed on May 1, 2019).

The Irish Times (2013), "Do the clothes on our backs leave blood on our hands?", May 13, available at: $\quad$ https://www.irishtimes.com/news/consumer/do-the-clothes-on-our-backs-leave-blood-on-our$\underline{\text { hands-1.1389030 }}$ (accessed on May 1, 2019)

The Japan Times (2013), “Who's to blame in Bangladesh?", May 12, available at: https://www.japantimes.co.jp/opinion/2013/05/12/editorials/whos-to-blame-in-bangladesh/\#.XM10N-

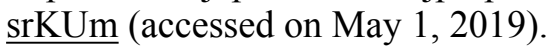

The New Age (2018), “Accord, Alliance to leave Bangladesh after December 7", July 18, available at: http://www.newagebd.net/article/46266/accord-alliance-to-leave-bangladesh-after-dec-7-tofail (accessed on May 1, 2019).

The New York Times (2012), "Fatal fire in Bangladesh highlights the dangers facing garments workers", November 25, available at:

https://www.nytimes.com/2012/11/26/world/asia/bangladesh-fire-kills-more-than-100-andinjures-many.html (accessed on May 1, 2019)

The Telegraph (2013), "Primark shocked by Bangladesh building collapse", April 30, available at: https://www.telegraph.co.uk/finance/newsbysector/retailandconsumer/10017011/Primark-shocked-byBangladesh-building-collapse.html (accessed on May 1, 2019).

Time (2013a), "Bangladesh factory collapse: is there blood on your shirt?", May 02, available at: http://business.time.com/2013/05/02/bangladesh-factory-collapse-is-there-blood-on-your-shirt/ (accessed on May 1, 2019)

Time (2013b), "In wake of Rana Plaza tragedy, Bangladesh garment factories inspections floundering", September 12, available at: http://world.time.com/2013/09/12/in-wake-of-rana-plaza-tragedybangladesh-garment-factory-inspections-floundering/ (accessed on May 1, 2019).

Tost, L. P. (2011), “An integrative model of legitimacy judgments”, Academy of Management Review 36 , pp. 686-710.

USTR (2013), "Statement by the US government on labor rights and factory safety in Bangladesh", Office of the United States Trade Representative, available at: https://ustr.gov/about-us/policyoffices/press-office/press-releases/2013/july/usg-statement-labor-rights-factory-safety (accessed on May 1, 2019). 
Van de Ven, A. H. and Poole, M. S. (2002), "Field research methods", In Baum, J. A. C. (Ed.), Companion to Organizations. New York: Oxford University Press, 867-88.

Vasi, I. B. and King, B. G. (2012), "Social movements, risk perceptions, and economic outcomes: the effect of primary and secondary stakeholder activism on firms' perceived environmental risk", American Sociological Review 77, pp. 573-96.

Vogel, D., (2008), "Private Global Business Regulation", Annual Review of Political Science, 11(1): 261-282. 
Table 1: List of interviewees

\begin{tabular}{|c|c|c|c|}
\hline $\begin{array}{c}\text { Interview } \\
\text { respondent }\end{array}$ & Designation & $\begin{array}{l}\text { Pseudo } \\
\text { initials }\end{array}$ & Gender \\
\hline 01 & RMG owner, chairman of the Board & $\mathrm{AH}$ & Male \\
\hline $02 \quad 2$ & Managing Director and owner & RH & Male \\
\hline 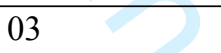 & Manager, RMG factory & $\overline{\mathrm{AI}}$ & Male \\
\hline 04 & Managing Director & $\mathrm{RC}$ & Female \\
\hline$\overline{3}$ & Managing Director, member of BGMEA board & SMS & Male \\
\hline 06 & Managing Director and owner & $\mathrm{RzC}$ & Male \\
\hline 07 & Managing Director & SB & Male \\
\hline 08 & Managing Director & FWA & Male \\
\hline 09 & Chief Operating Officer & STZ & Male \\
\hline 10 & AGM Compliance & MAZ & Male \\
\hline 11 & Operator & SM & Male \\
\hline 12 & Operator, direct manufacturer & DM & Male \\
\hline 13 & Operator & SA & Male \\
\hline 14 & Manager, RMG factory & AR & Male \\
\hline 15 & Operator & $\mathrm{BB}$ & Female \\
\hline 16 & Operator & TK & Female \\
\hline 17 & Manager, RMG factory & $\mathrm{AZ}$ & Male \\
\hline 18 & Manager & AT & Male \\
\hline 19 & Inspector, Accord & STA & Male \\
\hline 20 & Inspector, Alliance & MMA & Male \\
\hline 21 & Trade union leader & $\mathrm{JP}$ & Male \\
\hline 22 & President, RMG labor union & NA & Female \\
\hline 23 & Project Coordinator, ILO & JS & Male \\
\hline 24 & Project coordinator, GIZ & HA & Male \\
\hline 25 & $\begin{array}{l}\text { Director, Department of Inspection for Factories and } \\
\text { Establishments, GoB }\end{array}$ & \multirow{3}{*}{\multicolumn{2}{|c|}{$\begin{array}{l}\text { Interview conducted, but not } \\
\text { allowed to publish }\end{array}$}} \\
\hline 26 & Additional Secretary, Ministry of Commernce, GoB & & \\
\hline 27 & Secretary, Ministry of Labour and Manpower, GoB & & \\
\hline
\end{tabular}


Table 2: Initial template [underlying theoretical framework by Reincecke and Ansari (2016)]

\begin{tabular}{|c|c|c|}
\hline Initial frame & Mechanism & Expected pattern \\
\hline $\begin{array}{l}\text { Existence of a wicked } \\
\text { problem }\end{array}$ & $\begin{array}{l}\text { - } \text { Cognitive shortcuts } \\
\text { - } \text { Causal linkage } \\
\text { - } \\
\text { Emotional } \\
\text { connectivity }\end{array}$ & Construction of a responsibility frame \\
\hline $\begin{array}{l}\text { Construction of a } \\
\text { responsibility frame }\end{array}$ & $\begin{array}{l}\text { - Induction of social } \\
\text { judgements through } \\
\text { third party } \\
\text { disclosure } \\
\text { - } \begin{array}{l}\text { Induction of social } \\
\text { judgements through } \\
\text { self-disclosure }\end{array} \\
\end{array}$ & $\begin{array}{l}\text { Solidification of a responsibility } \\
\text { frame }\end{array}$ \\
\hline $\begin{array}{l}\text { Solidification of a } \\
\text { responsibility frame }\end{array}$ & $\begin{array}{l}\text { - Dialogue amongst } \\
\text { the major actors }\end{array}$ & $\begin{array}{l}\text { Corporate adoption of responsibility } \\
\text { frame }\end{array}$ \\
\hline
\end{tabular}




\section{Table 3: Private sector frame changes: the observed template}

\begin{tabular}{|c|c|c|c|}
\hline Initial frame & Mechanisms adopted & Expected pattern & Observed pattern \\
\hline $\begin{array}{l}\text { Existence of a wicked } \\
\text { problem }\end{array}$ & 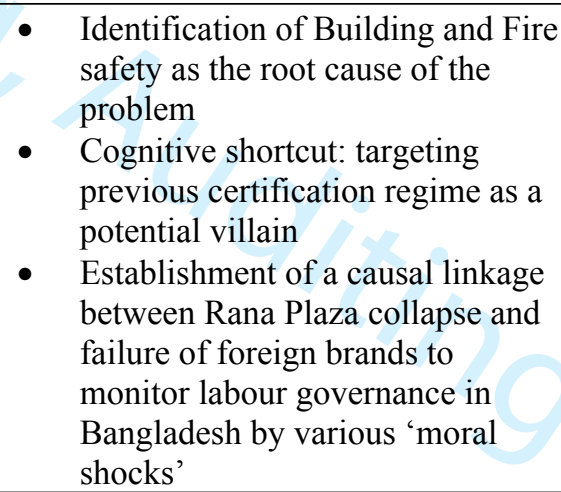 & $\begin{array}{l}\text { Construction of a responsibility } \\
\text { frame }\end{array}$ & $\begin{array}{l}\text { Foreign brands accepted responsibility to } \\
\text { address the labour governance issues in } \\
\text { the RMG sector in Bangladesh. }\end{array}$ \\
\hline $\begin{array}{l}\text { Construction of a } \\
\text { responsibility frame }\end{array}$ & $\begin{array}{l}\text { - Voluntary self-disclosures made } \\
\text { by different brands in annual } \\
\text { reports/websites regarding the } \\
\text { effectiveness of compliance } \\
\text { programmes in Bangladesh }\end{array}$ & $\begin{array}{l}\text { Solidification of a responsibility } \\
\text { frame }\end{array}$ & $\begin{array}{l}\text { The introduction of the Alliance and } \\
\text { Accord inspection regimes solidified the } \\
\text { responsibility framework }\end{array}$ \\
\hline $\begin{array}{l}\text { Solidification of a } \\
\text { responsibility frame }\end{array}$ & $\begin{array}{l}\text { Multistakeholder intiative to } \\
\text { approach GoB to extend the scope } \\
\text { and time frame of the certification } \\
\text { regime, as their work was not } \\
\text { complete }\end{array}$ & $\begin{array}{l}\text { Corporate adoption of responsibility } \\
\text { frame }\end{array}$ & $\begin{array}{l}\text { Indication of the assumption of a political } \\
\text { role by the brands }\end{array}$ \\
\hline
\end{tabular}


Figure 1: Labour gowenasce post-Rana plaza-a summary of liey events

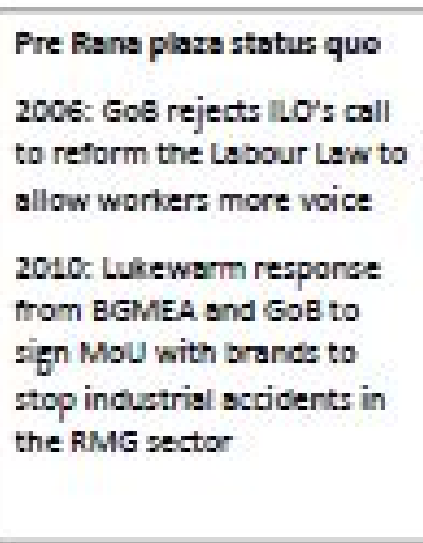
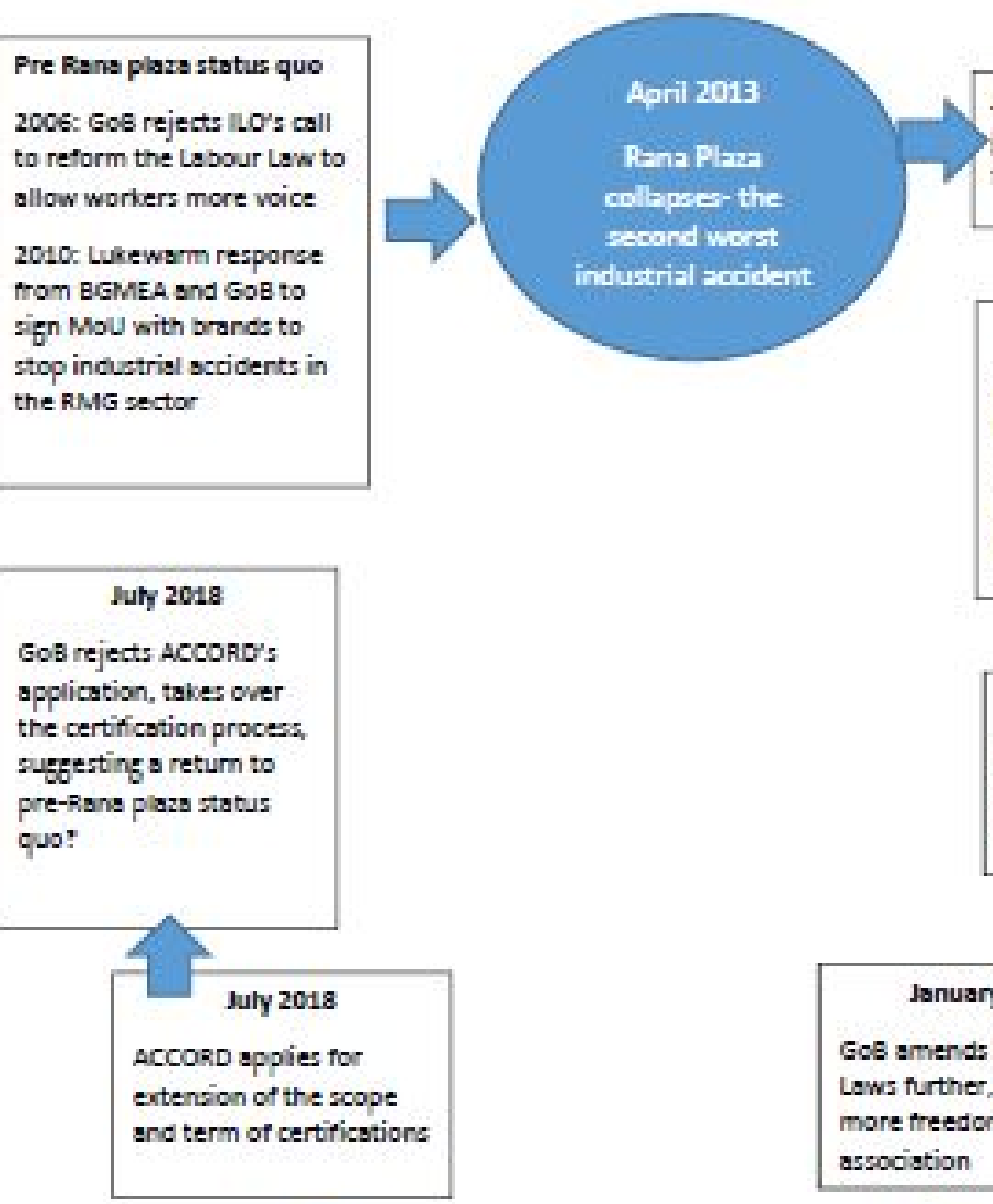

June 2013: US government cancels GSP faclites to Bangladerh

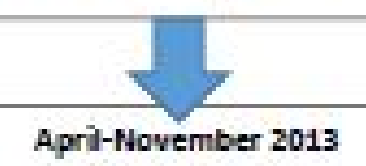

Aliance and Accord initiatives bunched Golamend: Labour Law, sgrees revised wages for the RMG sector

$$
\text { Augut } 2044
$$

Aliance and Accord publish their first. inspection results

\section{April 2017}

Aliance report brands Bargledesh RMS sector smorft worid's satest

GoE amend: Labour Laws further, allowirg more treedom of ascogation
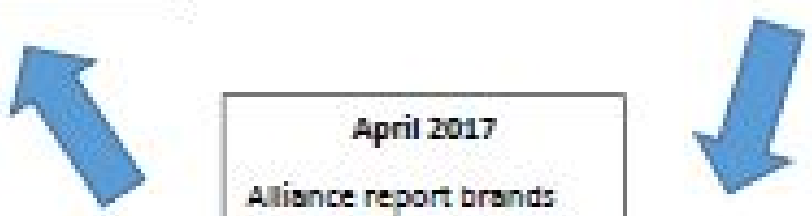